\title{
The Criminal Sanctions For Terrorism Crime Based On Terrorism Eradication Law And Islamic Law
}

\author{
Wahyu Sriyono*) and Lathifah Hanim**) \\ *Investigators at the Genuk Sector Police of Semarang City, Central Java E-mail: \\ Wahyusriyono007@gmail.com \\ ${ }^{* *}$ ) Faculty of Law Universitas Islam Sultan Agung
}

\begin{abstract}
The crime of terrorism is a crime that is very dangerous for the sovereignty of the state and causes many victims. Seeing the very dangerous impact, the perpetrators of terrorism must be given heavy criminal sanctions. This study aims to identify and examine criminal sanctions for perpetrators of criminal acts of terrorism based on Act No. 5 of 2018 and Islamic Law. This study uses a normative juridical approach, which is descriptive analysis. The data used is secondary data obtained through literature study, which is then analyzed qualitatively. The results of this study are criminal sanctions for perpetrators of criminal acts of terrorism based on Act No. 5 of 2018 are capital punishment, imprisonment, confinement, and criminal fines for corporations, while according to Islamic law perpetrators of criminal acts of terrorism are threatened with a hudud finger. This crime of terrorism is also included in the qishash finger which is sentenced to death if there is no pardon (amnesty).

Keywords: Islamic Law; Criminal Sanctions; Terrorism, Crime.
\end{abstract}

\section{Introduction}

The Republic of Indonesia as a state of law, as stipulated in Article 1 paragraph (3) of the 1945 Constitution of the Republic of Indonesia, has the duty and responsibility to maintain a safe, peaceful and prosperous life and to actively participate in maintaining world peace.

According to Aristotle, the rule of law is a state that stands above the law which guarantees justice for its citizens. Good law is a law that comes from a sense of community justice and who rules in the state is a fair mind, while the ruler is only the holder of law and balance ${ }^{1}$ The power possessed by the state is essentially a means to realize justice and welfare ${ }^{2}$ for his people.

In addition to this, protecting the entire Indonesian nation is also a duty that must be carried out by the government whose obligations are the basic rights of citizens without exception. ${ }^{3}$ It also mentions the 5th Pancasila principle which

\footnotetext{
${ }^{1}$ Nomensen Sinamo, 2014, Hukum Tata Negara Indonesia, Third Printing, Revised Edition, Permata Aksara, Jakarta, p. 36.

${ }_{2}^{2} J a w a d e$ Hafidz Arsyad, 2013, Korupsi Dalam Perspektif HAN (Hukum Administrasi Negara), First Printing, Sinar Graphic, Jakarta, p. 85.

${ }^{3}$ Farhan Munirus Su'aidi dan Abdullah Arief Cholil, Desember 2019, Law Protection on Wife Whose The Claims Fall Due To Husband Refuse His Recompensation On Implementing Of Divorce Pledge, Jurnal Daulat Hukum, Vol. 2 No. 4, Faculty of Law, Universitas Islam Sultan Agung, Semarang, url : http://jurnal.unissula.ac.id/index.php/RH/article/view/8367/3897, p. 548.
} 
reads: "Social justice for all Indonesian people", it can be explained that one of them is related to the law which is the right of the Indonesian people to justice in truth. ${ }^{4}$

In realizing social justice, the government is obliged to maintain and uphold sovereignty and protect every citizen from every threat or destructive threat, both domestically and abroad, such as acts or acts of terrorism. The existing criminal acts of terrorism must be countered by combating these acts of terrorism. ${ }^{5}$

The Government of the Republic of Indonesia has responded to the efforts and tips to anticipate and overcome these acts of terrorism and at the same time the enactment of a law to eradicate criminal acts of terrorism is Government Regulation in Lieu of Law (Perppu) Number 1 of 2002 concerning Eradication of Criminal Acts of Terrorism (State Gazette of the Republic of Indonesia). 2002 Number 106, Supplement to the State Gazette Number 4232) issued on October 18, 2002. Subsequently, this Perppu became law into Act No. 15 of 2003 concerning Stipulation of Government Regulations in Lieu of Act No. 1 of 2002 concerning Eradication of Criminal Acts Terrorism Becomes Law, on April 4, 2003, 6 then Act No. 15 of 2003 was amended by Act No. 5 of 2018 concerning Amendments to Act No. 15 of 2003 concerning Stipulation of Government Regulations in Lieu of Act No. 1 of 2002. As for the definition of terrorism according to the provisions of Article 1 point 2 of the Law -Act No. 5 of 2018 are:

Acts that use violence or threats of violence that create an atmosphere of terror or widespread fear, which can cause mass casualties, and/or cause damage or destruction to strategic vital objects, the environment, public facilities, or international facilities with ideological, political or security motives.

Meanwhile, the definition of a criminal act of terrorism according to the provisions of Article 1 point 1 of Act No. 5 of 2018 is: "All acts that meet the elements of a criminal act in accordance with the provisions of this Law".

The problem of terrorism became prominent when the tragedy of the World Trade Center (WTC) in New York, on September 11, 2001, was destroyed by two airplanes taking turns. The United States reacted quickly and declared war on terrorism, and declared a "new enemy", namely the terrorists.

Not only happening in other countries, acts of terrorism have also occurred in Indonesia until now. Between 2003 and 2005, a series of bombs continued to hit Indonesia, the largest being the JW Marriot hotel bombing (August 2003), the bombing in front of the Australian Embassy in Jakarta (September 2004) and the Bali 2 bombing (October 2005). The series of terrorism crimes interrupted and damaged the inner atmosphere of the Indonesian people who had just enjoyed a more free and open socio-political life. Terror acts that occurred in the reform era,

${ }^{4}$ Lailatul Nur Hasanah dan Sri Endah Wahyuningish, Desember 2019, The Application of Justice Principles Of Rapid Simple Fee In Criminal Justice System In The State Court (Case Study in State court of Pati), Jurnal Daulat Hukum, Vol. 2 No. 4, Faculty of Law, Universitas Islam Sultan Agung, Semarang, url : http://jurnal.unissula.ac.id/index.php/RH/article/view/8353/3910, p. 610.

${ }^{5}$ Sri Endah Wahyuningsih, Lathifah Hanim, dan Natalia Budi Darma, Maret 2018, Kebijakan Formulasi Hukum Pidana Dalam Penanggulangan Tindak Pidana Terorisme Di Indonesia, Jurnal Daulat Hukum, Vol. 1. No. 1, Faculty of Law, Universitas Islam Sultan Agung, Semarang, url : http://jurnal.unissula.ac.id/index.php/RH/article/view/2649/1993, hlm. 311.

${ }^{6}$ Didik M. Arief Mansur, 2007, Urgensi Perlindungan Korban Kejahatan, Raja Grafindo Persada, Jakarta, p. 130. 
according to the results of the research by the BNPT team, there were approximately 103 acts of terror that occurred, 41\% of which were aimed at places of worship, especially churches and Christian institutions, $43 \%$ of the actions were directed to public places such as malls, restaurants, cafes, hotels, office buildings and markets, while the rest is directed to government offices and foreign offices such as embassies in Indonesia. Although the church became the target of high levels of terror in the reform era, several bombs were detonated at mosques, such as the Istiqlal Mosque, Jakarta in 1978 and 1999 and the Polresta mosque, Cirebon in 2011. ${ }^{7}$

The perpetrators of terrorism, most of whom are Muslims, have tarnished the name of Islam as a religion that always maintains peace. The reason is jihad in the way of Allah SWT, so that the perpetrators do not care whether the victims are children or women. Islam is considered a religion that teaches violence, and that is not true. In Islam itself, acts of violence and unreasonable destruction are prohibited, even Allah SWT condemns those who make mischief on earth in QS Al Maidah verse 33.

Terrorism is a very difficult moral issue because there are no standardized boundaries, as Brian Jenkins said that terrorism is a subjective view, which is based on who sets limits at certain times and conditions so that it makes it difficult to define it. ${ }^{8}$ of course, terrorism is an act that deserves punishment, and terrorism itself has been regulated in positive law as mentioned above.

Law as a rule, norm, guideline, behavior, or statutory regulations which if violated will be subject to sanctions. Those who do wrong or break the rules must be punished. ${ }^{9}$ Every act or action that is against the law, will get criminal sanctions as regulated in criminal law. The essence of criminal law is the imposition of suffering or misery or other unpleasant consequences. ${ }^{10}$

Against criminal acts of terrorism, the criminal sanctions imposed are quite heavy considering the impact is also very large. Both Act No. 5 of 2018 and Islamic Law have determined criminal sanctions for perpetrators of criminal acts of terrorism, which are expected to eradicate criminal acts of terrorism and radicalism movements that endanger the Indonesian nation and state.

The purpose of this study is to find out and examine criminal sanctions for perpetrators of criminal acts of terrorism based on Act No. 5 of 2018 and Islamic Law.

\section{Research methods}

The type of research used in writing this legal journal is normative juridical. Normative juridical research is research that is focused on examining the

\footnotetext{
${ }^{7}$ Agus SB, 2014, Darurat Terorisme, Kebijakan Pencegahan, Perlindungan dan De-radikalisasi, Issue I, Daulat Press, Jakarta, p. 15.

${ }^{8}$ Abdurrahman et al., 2011, Al Qur'an dan Isu-isu Kontemporer, eLSAQ Press, Yogyakarta, p. 110. ${ }^{9}$ Jawade Hafidz Arsyad dan Dian Karisma, 2018, Sentralisasi Birokrasi Pengadaan Barang \& Jasa Pemerintah, First Printing, Sinar Graphic, Jakarta, p. 63.

${ }^{10}$ Sri Endah Wahyuningsih, 2013, Prinsip-Prinsip Individualisasi Pidana Dalam Hukum Pidana Islam dan Pembaharuan Hukum Pidana Indonesia, Second Printing, Publishing Agency Diponegoro University, Semarang, p. 80.
} 
application of rules or norms in positive law, ${ }^{11}$ which in this case relates to criminal sanctions for perpetrators of criminal acts of terrorism based on Act No. 5 of 2018 concerning Eradication of Criminal Acts of Terrorism and Islamic Law. This research is descriptive analysis, because the researcher wishes to describe or explain the subject and object of research, which then analyzes and finally draws conclusions from the results of the study. ${ }^{12}$ The data used in this research is secondary data. Secondary data is data obtained from library materials through library research, and this data is also obtained from agencies/institutions related to the purpose of this research. ${ }^{13}$ According to the data that has been obtained during the research by reading library books, then it is analyzed. The analysis used in this research is qualitative data analysis.

\section{Results and Discussion}

After the bombing of the WTC building on September 11, 2001, which was used as a reference for the world being hit by the terrorist threat, it was followed by bombings in other areas, including in Indonesia. Bombings in Indonesia have occurred many times, starting with the Bali bombings which killed many victims and destroyed the pace of economic development, especially the tourism industry in Indonesia.

According to Wawan $\mathrm{H}$. Purwanto, the threat of terrorism in Indonesia cannot be separated from the global political order that is now controlled by the US and its allies. In addition, the domestic political system also triggers acts of terrorism. With these two contexts, according to him, the threat of terrorism in Indonesia will continue to disrupt national, regional and international security. ${ }^{14}$

Considering that the criminal act of terrorism is very dangerous to the sovereignty of the state and human life, then the act must be punished for the perpetrators. Not only to provide a deterrent effect for the perpetrators, but also to protect the public from these radical actions.

Crime is one of the main problems in criminal law, in addition to criminal acts and criminal liability. If interpreted broadly, the criminal system includes a process of giving or imposing a crime by a judge, then the crime is only a small part of the criminal system. ${ }^{15}$

Broadly speaking, it can be said that the criminal system includes all the provisions of the legislation governing how the criminal law is enforced or operationalized in a concrete way so that a person is sentenced to a crime. ${ }^{16}$ Thus,

\footnotetext{
11Jhonny Ibrahim, 2011, Teori dan Metodologi Penelitian Hukum Normatif, Bayumedia, Malang, p. 295. ${ }_{12}$ Mukti Fajar ND dan Yulianto Achmad, 2010, Dualisme Penelitian Hukum Normatif dan Empiris, Pustaka Pelajar, Yogyakarta, p. 183.

${ }^{13}$ Soeratno dan Lincolin Arsyad, 2003, Metodologi Penelitian Untuk Ekonomi Dan Bisnis, UPP AMP YKPN, Yogyakarta, p. 173.

${ }^{14}$ Mardenis, 2013, Pemberantasan Terorisme, Politik Internasional dan Politik Hukum Nasional Indonesia, First Edition, Second Printing, Raja Grafindo Persada, Jakarta, p. 126.

${ }^{15}$ Ali Masyhar, 2009, Gaya Indonesia Menghadang Terorisme, Sebuah Kritik Atas Kebijakan Hukum Pidana Terhadap Tindak Pidana Terorisme Di Indonesia, First Printing, Mandar Maju, Bandung, p. 124. 16Barda Nawawi Arief, 2002, Bunga Rampai Hukum Pidana, Citra Aditya Bakti, Bandung, p. 117.
} 
all laws and regulations concerning substantive criminal law, formal criminal law and criminal law enforcement must be viewed as a unified criminal system.

Today's criminal law must be adapted to the nature and style of crimes that arise in accordance with the times and the development of society. On the other hand, if criminal law and law enforcement do not adapt to the nature and style of the ever-evolving crime, then the criminal law will not be able to achieve its function, namely providing protection for the sake of creating community welfare. ${ }^{17}$

Criminal law, compared to other branches of law, is a law that is equipped with strict criminal sanctions. Crime is a suffering that is intentionally imposed on people who commit acts that meet certain conditions (committing a crime).${ }^{18}$ Because it is a suffering or misery, caution is needed in imposing a crime including its determination/formulation. Criminal determination does not mean without a purpose. The criminal determination must be based on reasonable or rational considerations that are oriented towards the goals to be achieved. ${ }^{19}$

The imposition of a crime by a judge is a series of law enforcement processes. Law enforcement has a strategic position. Law enforcement in a macro sense covers all aspects of people's lives, as a nation and state, while in a micro sense law enforcement is limited in the litigation process in court, both in civil cases, state administration and in criminal cases including the process of investigation, investigation, prosecution (examination before the trial) until the implementation of court decisions that have permanent legal force. ${ }^{20}$

Law enforcement and justice in a fair or just legal process are enforcement guaranteed by the 1945 Constitution of the Republic of Indonesia which provides protection and benefits for every citizen in the context of upholding the supremacy of the constitution as the basic law of the state. ${ }^{21}$ Law enforcement is one of the parameters in the success of the rule of law. ${ }^{22}$ Consistent law enforcement will provide a sense of security, justice and certainty. ${ }^{23}$

The ultimate goal of criminal law enforcement is to tackle crime by punishing every guilty person with criminal sanctions. In this context, every criminal justice process must be based on due process of law. Because as a "truth determination" process that confronts a suspect in an examination, where the legal apparatus has

\footnotetext{
${ }^{17}$ Edi Setiadi dan Kristian, 2017, Peradilan Pidana Terpadu Dan Sistem Penegakan Hukum Di Indonesia, First Printing, Kencana Prenada Media Group, Jakarta, p. 3.

${ }^{18}$ Soedarto, 1990, Hukum Pidana I, Yayasan Soedarto, Semarang, p. 9.

${ }^{19}$ Ali Masyhar, op.cit., p. 124-125.

20Marwan Effendy, 2012, Diskresi, Penemuan Hukum, Korporasi \& Tax Amnesty Dalam Penegakan Hukum, p. 2.

${ }^{21}$ Abdul Latif, 2014, Hukum Administrasi Dalam Praktik Tindak Pidana Korupsi, First Printing, First Edition, Kencana Prenada Media, Jakarta, p. 162 and 163.

${ }^{22}$ Sri Endah Wahyuningsih dan Rismato, Januari-April 2015, Kebijakan Penegakan Hukum Pidana Terhadap Penanggulangan Money Laundering Dalam Rangka Pembaharuan Hukum Pidana Di Indonesia, Jurnal Pembaharuan Hukum, Vol. II No. 1, Faculty of Law, Universitas Islam Sultan Agung, Semarang, url : http://jurnal.unissula.ac.id/index.php/PH/article/ view/1414/1087, p. 46-47.

${ }^{23}$ Anggrin Gayuh Praptiwi dan Lathifah Hanim, September 2019, Effectiveness And Role Of The Food Duty Unit Of Police Region Of Central Java In Law Enforcement In The Field Of Food In The Regional Law Of POLDA Central Java, Jurnal Daulat Hukum, Vol. 2 No. 3, Faculty of Law, Universitas Islam Sultan Agung, Semarang, url : http://jurnal.unissula.ac.id/ index.php/ RH/article/view/5669/3416, p. 387.
} 
great legal authority, the criminal justice process must be carried out according to the principles of a fair legal process. ${ }^{24}$

Opinions that can be categorized as still considering the need for criminal sanctions to be used in crime prevention are expressed by many experts, including Roeslan Saleh. Roeslan Saleh suggested 3 (three) reasons regarding the need for criminal and criminal law, namely: 25

- Whether or not criminal law is necessary does not lie in the question of the goals to be achieved, but lies in the question of how far to achieve that goal it is permissible to use coercion;

- There are efforts to repair or maintain that have no meaning at all for the convicted person, and besides that there must be a reaction to the violations of norms that he has committed and cannot be left alone;

- The influence of criminal or criminal law is not solely aimed at the maker, but also to influence people who are not evil, namely citizens who obey the norms of society.

According to Alf Ross, that the criminal conception departs from 2 (two) requirements or objectives, namely: ${ }^{26}$

- The crime is aimed at imposing suffering on the person concerned;

- Crime is a statement of reproach to the actions of the perpetrator.

The two conditions stated by Alf Ross above are intended to distinguish between crime and action (treatment). According to him, can not be considered as a crime, things as follows: ${ }^{27}$

- Actions that aim to cause suffering but do not constitute a statement of reproach, for example giving an "electric shock" to an animal in a study so that its behavior can be observed or controlled;

- Actions which constitute a statement of reproach but are not intended to inflict suffering, for example reprimands, warnings or exclusion by the public;

- Actions that are not intended to cause suffering, are also not a statement of reproach, such as the act of a dentist pulling out a patient's tooth.

Criminal law can be interpreted as suffering or misery carried out by the competent authority on behalf of the state against someone who has violated certain rules, while punishment itself can be interpreted as a stage in determining sanctions and the stage of imposing sanctions in criminal law. ${ }^{28}$

In fact, many of its articles threaten the death penalty. The death penalty is formulated in the following articles: ${ }^{29}$

- Article 6 (using violence or threats of violence creates an atmosphere of terror and victims are mass);

\footnotetext{
24Theodorus Yosep Parera, 2016, Advokat dan Penegakan Hukum, First Printing, Genta Press, Yogyakarta, p. 19-20.

25Barda Nawawi Arief, 2000, Kebijakan Legislatif Dalam Penanggulangan Kejahatan Dengan Pidana Penjara, Badan Penerbit Undip, Semarang, p. 20.

${ }^{26}$ Ari Wibowo, 2012, Hukum Pidana Terorisme, Kebijakan Formulatif Hukum Pidana Dalam Penanggulangan Tindak Pidana Terorisme Di Indonesia, First Printing, Graha Ilmu, Yogyakarta, p. 26. 27Ibid., p. 27.

28 Ibid

${ }^{29}$ Ali Masyhar, op.cit., p. 136-137.
} 
- Article 8 (crimes against aviation facilities and infrastructure);

- Article 9 (related to firearms for committing criminal acts of terrorism);

- Article 10 (using chemical weapons and their components to incite terrorism);

- Article 14 (planning/moving other people to commit terrorism); and

- Article 15 (malicious conspiracy, trial or assistance to criminal acts of terrorism).

In addition to the death penalty, imprisonment seems to be a criminal threat that dominates the formulation of threats in Act No. 5 of 2018. The threat of imprisonment is formulated alternatively with the death penalty and some are formulated as independent punishment, meaning that it is not alternatively used with other crimes. In Act No. 5 of 2018 the length of criminal sanctions (strafmaat) varies $^{30}$ between imprisonment for a certain period of time up to life.

In Act No. 5 of 2018, there are only a few articles that include threats of imprisonment and fines. The penalty of confinement is only formulated in one article, namely Article 23 which is threatened against witnesses and other people who mention the name or address of the reporter or other things that allow the identity of the reporter to be known.

Fines are only threatened for terrorism crimes committed by corporations. Through this formulation, it is as if a corporation can only be subject to "civil liability", so that a custodial crime cannot be imposed on a corporation. Whereas custodial crimes should also be applied, for example: suspension (cessation of corporate operations) for a certain period of time is essentially a prison. Freezing/revocation of operating license for ever can be interpreted as a death penalty or restrictions on movement, reduction of certain rights, announcement of judge's decision, and others. So the imposition of fines is actually not the only type of crime for corporations. ${ }^{31}$

Additional penalties are, in principle, facultative, but to be imposed they must be included in the formulation of the offense. Regarding the formulation of additional penalties, Act No. 5 of 2018 can be said to not include additional criminal threats. Only a few articles contain the possibility of imposing additional criminal charges, namely:

- Suspension or revocation of a corporation's license, and the corporation is declared a prohibited corporation [Article 18 paragraph (3)];

- confiscation of assets that have been confiscated [Article 35 paragraph (5)];

Regarding the pattern of criminal formulation, Act No. 5 of 2018 formulates in 6 (six) forms of formulation, namely: ${ }^{32}$

- Death penalty or life imprisonment or certain imprisonment (with minimum and maximum limits);

- Life imprisonment;

- Imprisonment (with minimum and maximum limits);

- Death penalty or life imprisonment;

- Fines (with a maximum limit);

- Criminal Cage: V.

\footnotetext{
30Mahrus Ali, 2012, Hukum Pidana Terorisme, Teori dan Praktik, Gramata Publishing, Jakarta, p. 245. ${ }^{31}$ Ibid., p. 138-139.

32 Ibid.
} 
Based on the identification above, it means that Act No. 5 of 2018 adheres to 2 (two) formulation systems, namely:

- Single formulation (threatened only with one principal sentence); and

- Alternative formulation.

The main punishment that is threatened singly is only imprisonment (both for life and imprisonment for a certain time), confinement and fines, while there is no death penalty that is threatened singly, alternatives are always formulated with life imprisonment and imprisonment for a certain time.

The formulation system as adopted by Act No. 5 of 2018 (especially the single formulation system) contains rigid, absolute and imperative properties. This system does not provide an opportunity for judges to determine what type of punishment is considered most suitable for the accused. With the formulation of the system, it does not provide space for judges to individualize punishments that are peopleoriented, especially in determining the type of crime. For the individualization of punishment, it is necessary to have flexibility or elasticity of punishment even though it remains within the limits of freedom determined by law. ${ }^{33}$

All formulations of imprisonment (within a certain time) which are formulated in Act No. 5 of 2018 include the minimum and maximum limits. Especially regarding the minimum limit, in certain circumstances it may even ignore the sides of justice. For example: a person who due to negligence causes a sign or tool for flight security to be destroyed, damaged, taken or moved (violating Article 8 letter d of Act No. 5 of 2018), is threatened with a minimum imprisonment of 4 years (a maximum of 20 years and even a maximum of 20 years). life imprisonment or death penalty). If this is actually practiced, it is certainly unfair to the convict. ${ }^{34}$

In Islamic law, the crime of terrorism is equated with the finger of rebellion (al-baghyu). Rebellion is an act of fighting against Allah and the Messenger, but by using excuses ( $\left.t a^{\prime} w i l\right)$. These reasons are usually political reasons, so the actions taken are not just to create chaos and disrupt security, but actions whose target is to take over power or overthrow the legitimate government. ${ }^{35}$ The crime of terrorism in Islamic law is also included in the crime of murder, because the crime of terrorism kills people, and the number of victims of terrorism is not small. The crime of terrorism which resulted in the death of many victims is very contrary to the Qur'an, so that the perpetrators of the crime of terrorism must be punished or punished for their actions.

Among the fuqaha, there are those who argue that there are 3 (three) kinds of criminal acts when viewed from a legal perspective, namely jarimah hudud, jarimah qishash or Diyat and jarimah ta'zir. But there are also those who classify 4 (four) kinds of 'uqubat in the form: ${ }^{36}$

- Al-Hudud, certain and absolute legal sanctions that are the right of Allah, which cannot be changed by anyone. Sanctions must be implemented, if the conditions

\footnotetext{
33Ibid., p. 140.

34Ibid., p. 144.

${ }^{35}$ Ahmad Wardi Muslich, 2005, Hukum Pidana Islam, First Printing, Sinar Graphic, Jakarta, p. 94.

36Teguh Prasetyo and Abdul Halim Barkatullah, 2005, Politik Hukum Pidana, Kajian Kebijakan Kriminsalisasi dan Dekriminalisasi, Pustaka Pelajar, Yogyakarta, p. 138.
} 
of the crime are met. This sanction is imposed on serious crimes such as adultery, sariqah, riddah, qadzaf, and others;

- Al-Qishash and al-Diyat. Al-Qishash is a punishment of balanced retaliation, such as killing the killer. Al-Diyat is a punitive sanction in the form of compensation, such as if the heirs of the murdered apologize then the alternative punishment is Diyat.

The legal sanctions of al-Qishash and al-Diyat are legal sanctions that are a combination of Allah's rights and human rights. ${ }^{37}$

- Al-Ta'zir is a legal sanction that is submitted to the decision of a judge or competent authority to carry out the sentence, such as imprisonment, exile, and others;

- Kafarat and fidyah are legal sanctions in the form of paying fines, which are handed over to the violator for implementation. The form of this fine can be in the form of freeing slaves, fasting, slaughtering or feeding the poor.

So in Islamic law, perpetrators of terrorism are threatened with a hudud finger. This crime of terrorism is also included in the qishash finger which is sentenced to death if there is no pardon (amnesty). If the perpetrators have surrendered and laid down their weapons, the crackdown is stopped and the rebels are guaranteed the safety of their lives and property, then the government (ulil amri) may pardon them or punish them with ta'zir punishment. Meanwhile, criminal acts that are not directly related to terrorism are sentenced to hudud according to the finger they have committed. The qishash punishment for intentional murder is the principal punishment. If the punishment cannot be carried out, due to reasons justified by the syara', then the substitute punishment is diyat.

Islamic law plays an important role in shaping and fostering social order for Muslims and influencing all aspects of their lives, so the best way that can be taken is to seek scientifically transforming Islamic legal norms into national law. ${ }^{38}$

\section{Closing}

Criminal sanctions for perpetrators of criminal acts of terrorism based on Act No. 5 of 2018 are capital punishment, imprisonment, imprisonment, and fines for corporations, while according to Islamic law perpetrators of terrorism are threatened with a hudud finger. This crime of terrorism is also included in the qishash finger which is sentenced to death if there is no pardon (amnesty). The government must take firm action against terrorist acts that occur in Indonesia, as well as on radical actions. The government also needs to provide socialization to the public regarding radical actions in the name of religion, which are contrary to religion.

\section{References}

\section{Journal}

\footnotetext{
37Ibid., p. 139.

38Mardani, 2013, Hukum Islam, Kumpulan Peraturan tentang Hukum Islam di Indonesia, First Printing, Second Edition, Kencana Prenada Media Group, Jakarta, p. 12.
} 
[1] Anggrin Gayuh Praptiwi dan Lathifah Hanim, September 2019, Effectiveness And Role of The Food Duty Unit Of Police Region Of Central Java In Law Enforcement In The Field of Food In The Regional Law Of POLDA Central Java, Jurnal Daulat Hukum, Vol. 2 No. 3, Faculty of Law, Universitas Islam Sultan Agung, Semarang, url http://jurnal.unissula.ac.id/index.php/RH/article/view/5669/3416.

[2] Farhan Munirus Su'aidi dan Abdullah Arief Cholil, Desember 2019, Law Protection on Wife Whose The Claims Fall Due To Husband Refuse His Recompensation On Implementing Of Divorce Pledge, Jurnal Daulat Hukum, Vol. 2 No. 4, Faculty of Law, Universitas Islam Sultan Agung, Semarang, url : http://jurnal.unissula.ac.id/index.php/RH/article/view/8367/3897.

[3] Lailatul Nur Hasanah dan Sri Endah Wahyuningish, Desember 2019, The Application of Justice Principles Of Rapid Simple Fee In Criminal Justice System In The State Court (Case Study in State court of Pati), Jurnal Daulat Hukum, Vol. 2 No. 4, Faculty of Law, Universitas Islam Sultan Agung, Semarang, url : http://jurnal.unissula.ac.id/index.php/RH/article/view/8353/3910.

[4] Sri Endah Wahyuningsih dan Rismato, Januari-April 2015, Kebijakan Penegakan Hukum Pidana Terhadap Penanggulangan Money Laundering Dalam Rangka Pembaharuan Hukum Pidana Di Indonesia, Jurnal Pembaharuan Hukum, Vol. II No. 1, Faculty of Law, Universitas Islam Sultan Agung, Semarang, url : http://jurnal.unissula.ac.id/index.php/PH/article/ view/1414/1087.

[5] Sri Endah Wahyuningsih, Lathifah Hanim, dan Natalia Budi Darma, Maret 2018, Kebijakan Formulasi Hukum Pidana Dalam Penanggulangan Tindak Pidana Terorisme Di Indonesia, Jurnal Daulat Hukum, Vol. 1. No. 1, Faculty of Law, Universitas Islam Sultan Agung, Semarang, url : http://jurnal.unissula.ac.id/index.php/RH/article/view/2649/1993.

\section{Book}

[1] Abdul Latif, 2014, Hukum Administrasi Dalam Praktik Tindak Pidana Korupsi, First Printing, First Edition, Kencana Prenada Media, Jakarta

[2] Abdurrahman et al., 2011, Al Qur'an dan Isu-isu Kontemporer, eLSAQ Press, Yogyakarta

[3] Agus SB, 2014, Darurat Terorisme, Kebijakan Pencegahan, Perlindungan dan De-radikalisasi, Issue I, Daulat Press, Jakarta

[4] Ahmad Wardi Muslich, 2005, Hukum Pidana Islam, First Printing, Sinar Graphic, Jakarta

[5] Ali Masyhar, 2009, Gaya Indonesia Menghadang Terorisme, Sebuah Kritik Atas Kebijakan Hukum Pidana Terhadap Tindak Pidana Terorisme Di Indonesia, First Printing, Mandar Maju, Bandung

[6] Ari Wibowo, 2012, Hukum Pidana Terorisme, Kebijakan Formulatif Hukum Pidana Dalam Penanggulangan Tindak Pidana Terorisme Di Indonesia, First Printing, Graha Ilmu, Yogyakarta.

[7] Barda Nawawi Arief, 2000, Kebijakan Legislatif Dalam Penanggulangan Kejahatan Dengan Pidana Penjara, Badan Penerbit Undip, Semarang

[8] Barda Nawawi Arief, 2002, Bunga Rampai Hukum Pidana, Citra Aditya Bakti, Bandung 
[9] Didik M. Arief Mansur, 2007, Urgensi Perlindungan Korban Kejahatan, Raja Grafindo Persada, Jakarta

[10] Edi Setiadi dan Kristian, 2017, Peradilan Pidana Terpadu Dan Sistem Penegakan Hukum Di Indonesia, First Printing, Kencana Prenada Media Group, Jakarta.

[11] Jawade Hafidz Arsyad dan Dian Karisma, 2018, Sentralisasi Birokrasi Pengadaan Barang \& Jasa Pemerintah, First Printing, Sinar Graphic, Jakarta

[12] Jawade Hafidz Arsyad, 2013, Korupsi Dalam Perspektif HAN (Hukum Administrasi Negara), First Printing, Sinar Graphic, Jakarta

[13] Jhonny Ibrahim, 2011, Teori dan Metodologi Penelitian Hukum Normatif, Bayumedia, Malang

[14] Mahrus Ali, 2012, Hukum Pidana Terorisme, Teori dan Praktik, Gramata Publishing, Jakarta

[15] Mardani, 2013, Hukum Islam, Kumpulan Peraturan tentang Hukum Islam di Indonesia, First Printing, Second Edition, Kencana Prenada Media Group, Jakarta

[16] Mardenis, 2013, Pemberantasan Terorisme, Politik Internasional dan Politik Hukum Nasional Indonesia, First Edition, Second Printing, Raja Grafindo Persada, Jakarta

[17] Marwan Effendy, 2012, Diskresi, Penemuan Hukum, Korporasi \& Tax Amnesty Dalam Penegakan Hukum

[18] Mukti Fajar ND dan Yulianto Achmad, 2010, Dualisme Penelitian Hukum Normatif dan Empiris, Pustaka Pelajar, Yogyakarta

[19] Nomensen Sinamo, 2014, Hukum Tata Negara Indonesia, Third Printing, Revised Edition, Permata Aksara, Jakarta

[20] Soedarto, 1990, Hukum Pidana I, Yayasan Soedarto, Semarang

[21] Soeratno dan Lincolin Arsyad, 2003, Metodologi Penelitian Untuk Ekonomi Dan Bisnis, UPP AMP YKPN, Yogyakarta

[22] Sri Endah Wahyuningsih, 2013, Prinsip-Prinsip Individualisasi Pidana Dalam Hukum Pidana Islam dan Pembaharuan Hukum Pidana Indonesia, Second Printing, Publishing Agency Diponegoro University, Semarang

[23] Teguh Prasetyo and Abdul Halim Barkatullah, 2005, Politik Hukum Pidana, Kajian Kebijakan Kriminsalisasi dan Dekriminalisasi, Pustaka Pelajar, Yogyakarta

[24] Theodorus Yosep Parera, 2016, Advokat dan Penegakan Hukum, First Printing, Genta Press, Yogyakarta. 